\title{
PRELIMINARY RESULTS AND INTERPRETATIONS OF MINERAL MAGNETIC ANALYSES OF A HOLOCENE SEDIMENT SUCCESSION FROM LAKE MAARDU NEAR TALLINN, ESTONIA
}

\begin{abstract}
A core from Lake Maardu, $15 \mathrm{~km}$ east of Tallinn in the Republic of Estonia, has been analysed with respect to magnetic parameters. The $570 \mathrm{~cm}$ long core consists of gyttja resting on fine sand. Pollen, chemical composition, and magnetic analyses of this core have been carried out. The magnetic analyses include the determination of magnetic susceptibility and induced remanences in a forward field of 1 Tesla and a backfield of 0.1 Tesla. Radiocarbon dates and pollen diagrams as well as physical and chemical analyses, based on cores collected in 1988, were published by Saarse et al. (Caapce et al., 1990). A radiocarbon date from this paper of $9655 \pm 70{ }^{14} \mathrm{C}$ years BP in the lowermost part of the gyttja dates the onset of the organic sedimentation. There is also stratigraphical evidence near the top of the period, between 1894 and 1939, when the lake was dried out. Despite the magnetically very weak sediments, a number of features can be identified in the magnetic records. These features are assumed to reflect changing conditions in the environment due to natural and anthropogenic effects. Two periods of human impact are indicated, the first one starting at around $280 \mathrm{~cm}$ and the second at $180 \mathrm{~cm}$. Disturbances in the catchment due to human activity have caused increased erosion, seen in the magnetic records as alterations of the magnetic parameters. Both these periods are characterized by increasing magnetic concentrations, accompanied by a drop in the S-ratio as opposed to the periods with no human influence. In the lowermost part of the sediment succession variations in magnetic mineralogies are interpreted as the result of the Ancylus transgression, reflected as a period of lower S-ratios. A corresponding peak in the concentration parameters could be explained by changes in particle size distributions.
\end{abstract}

\section{Introduction}

The ubiquitous nature of iron oxides in rocks, soils, and virtually all types of sediments makes their study significant. Magnetic measurements can be applied to solve problems in subjects as diverse as, e. g., geophysics, meteorology, climatology, hydrology, oceanography, sedimentology, geomorphology, soil science, ecology, and land-use studies. As iron compounds are very sensitive to both natural and anthropogenic processes, magnetic analyses have become a useful technique also in lake sediment studies.

* Lunds Universitet, Kvartärgeologiska Avdelningen (Department of Quaternary Geology, Lund University), Tornavägen 13, S-22363 Lund. Sverige. 
The first cores from Lake Maardu were collected in 1988. Results from these cores were published in 1990 (Caapce et al., 1990). These investigations included determination of litho- and biostratigraphy and palaeogeographical development of the lake area. In addition four radiocarbon dates were carried out. In this paper results of magnetic analyses carried out on a core collected in 1991 will be presented and discussed.

\section{General Geology and Palaeogeography}

Lake Maardu (previously called Lake Liivakandi) is situated in Maardu glint bay between Iru and Maardu glint headlands, on the North-Estonian carbonaceous plateau, $15 \mathrm{~km}$ east of Tallinn (Fig. 1). The lake is very shallow with a maximum water depth of $3 \mathrm{~m}$. The present-day lake level is approximately $32 \mathrm{~m}$ a.s.l. Its surface water area is $168 \mathrm{ha}$ and the lake has a catchment area of about three times its surface area. During the Holocene there has been very little inflow and the lake has predominantly been fed by precipitation.

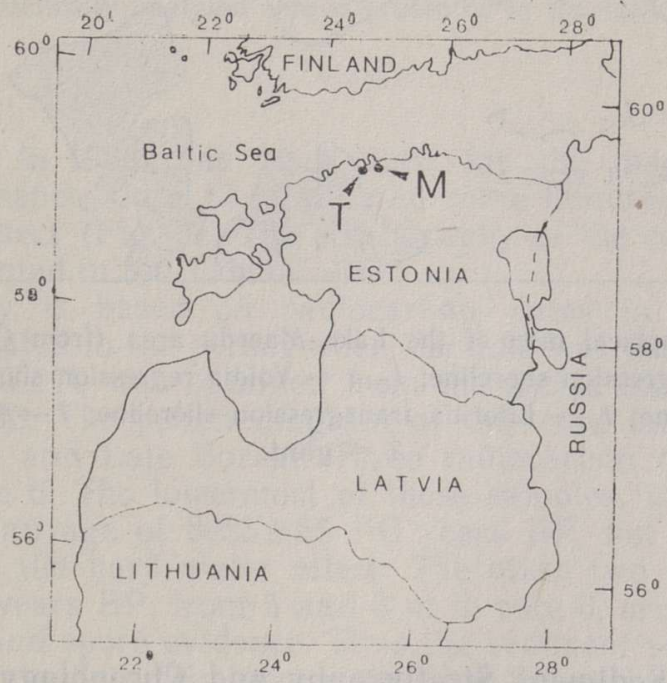

Fig. 1. Location of Lake Maardu. T - Tallinn, $\mathbf{M}$ - Lake Maardu.

According to the palaeogeographical map, Fig. 2 (from Caapce et al., 1990), the Yoldia Sea transgression maximum reached far above the present-day water level. The lake became isolated during the following regressional phase. During the Ancylus Stage the water level rose to ca $35 \mathrm{~m}$. The spit damming the lake today is assumed to have formed during the Ancylus Stage. The later Litorina transgression did not affect Lake Maardu at all.

In Maardu glint bay the bedrock is strongly eroded. There are outcrops of limestone of the Kunda and Lasnamäe stages. The surficial deposits in the catchment consist of sand, gravel, and till. 


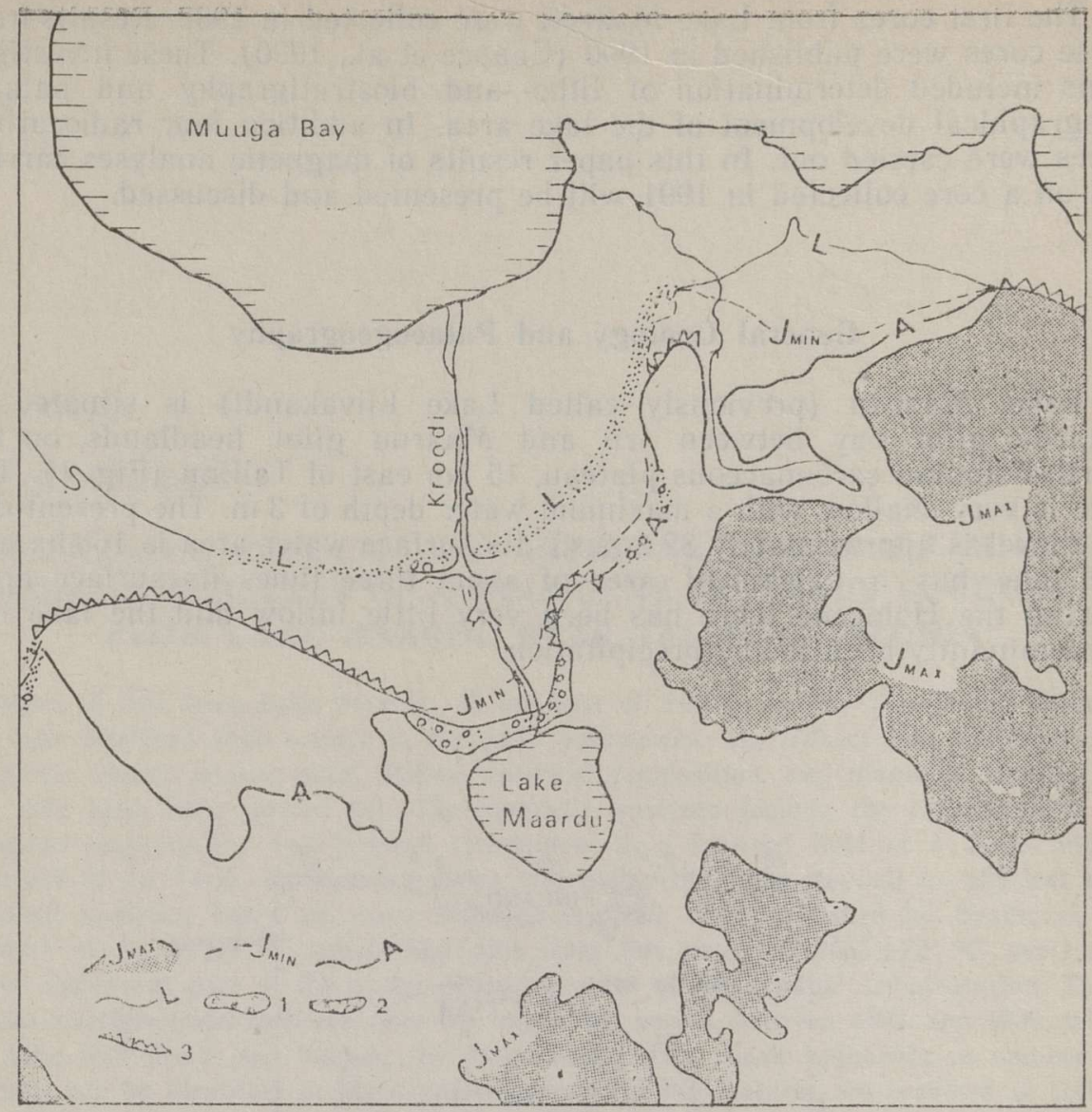

Fig. 2. Palaeogeographical map of the Lake Maardu area (from Caapce et al., 1990). $J_{\text {MAX }}$ - Yoldia transgression shoreline; $J_{\text {MIN }}$ - Yoldia regression shoreline; $A$ - Ancylus transgression shoreline; $L$ - Litorina transgression shoreline; 1 -spit, 2 - beach ridge, 3 - glint.

\section{Sediment Stratigraphy and C̄hronology}

A cross section trending approximately north-south was cored from ice in 1988 (Fig. 3). The section consists of eight cores with about $200 \mathrm{~m}$ between each coring point. All corings reached the sandy subsurface although the sand has not been cored through. The total thickness of organic sediments in the central part of the basin is almost $6 \mathrm{~m}$ (Fig. 2). Apart from a thin layer of silty gyttja resting on the sand in the southern part of the basin, the sediments consist of algal gyttja. In the very top of the sediment succession a thin $(\mathrm{ca} 10 \mathrm{~cm})$ greenish-black layer with a bad odour is found. This so-called "Soviet layer" consists of gyttja that is calcareous and sandy. It is in turn resting on a "sod layer," documented in the southern part of the cross section. This dark brown "sod layer" also consists of gyttja but is mixed with plant remains and roots. It was formed between 1894 and 1939, during the period when the lake dried up due to the break of an artificial dam. A sediments core collected close to 


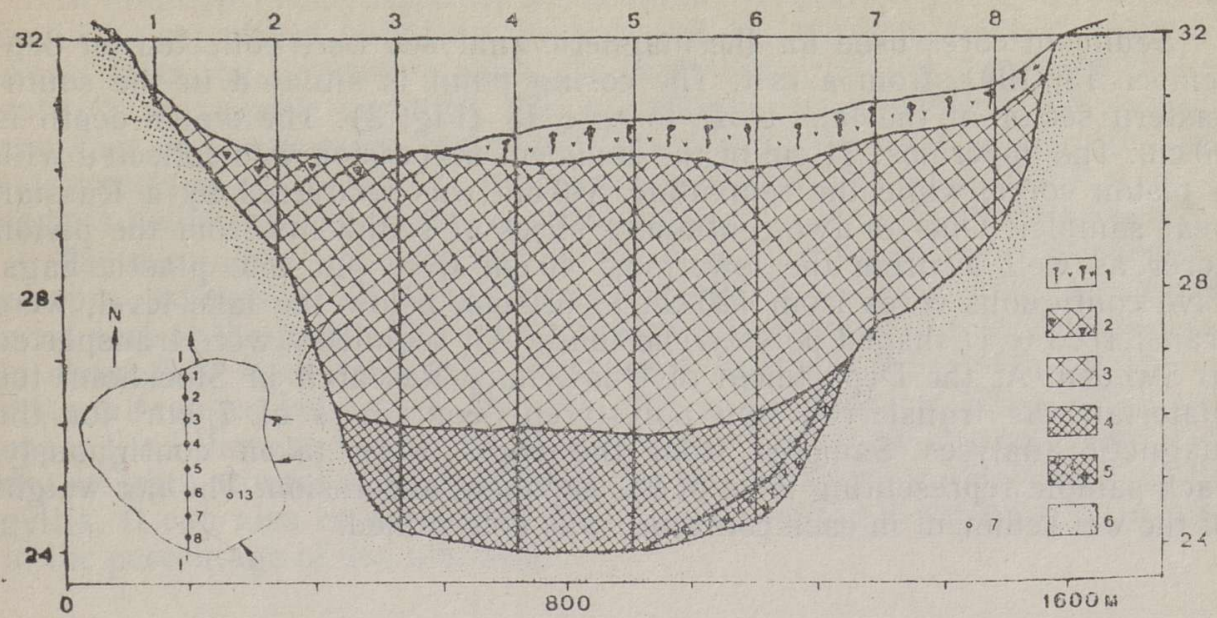

Fig. 3. Stratigraphy of the sediments in Lake Maardu based on eight cores along a north-south transect. The cores for the magnetic analyses were collected close to core 13 shown in the lower left figure (from Caapce et al., 1990). The stratigraphy of the magnetically analysed core is presented in the Table.

core 13 , recovered in 1988 , has been used for the magnetic analyses presented in this paper. Core 13 is situated some hundred meters east of core 6 on the transect (Fig. 3). The stratigraphy of the core discussed in this paper is presented in the Table.

The chronology is based on radiocarbon dates in addition to the historical dates related to the period when the lake was dried out. A radiocarbon age of $9655 \pm 70$ was obtained from the gyttja immediately above the sand in core 13. The pollen diagram of this core indicates a hiatus between Preboreal and Late Boreal. Three radiocarbon dates have been obtained from core 6 . The lowermost of these samples, in the top of the silty gyttja, gave an age of $8625 \pm 85{ }^{14} \mathrm{C}$ years $\mathrm{BP}$, but could be somewhat older due to the hard water effect. The other two dates, $6495 \pm 80$ and $3600 \pm 60{ }^{14} \mathrm{C}$ years $\mathrm{BP}$, from 5 and $3 \mathrm{~m}$ in core 6 , are in good agreement with pollen and spore evidence. Thus the sediment succession seems to represent a more or less continuous record of the entire Holocene.

Stratigraphy of the investigated core

\begin{tabular}{|c|c|c|}
\hline Depth, m & Unit & Stratigraphy \\
\hline $0.00-0.90$ & & Water \\
\hline $0.90-1.03$ & 1 & $\begin{array}{l}\text { 'Soviet' layer - gyttja, calcareous, sandy, greenish-black, } \\
\text { with bad odour }\end{array}$ \\
\hline $\begin{array}{l}1.03-1.25 \\
1.25-1.90\end{array}$ & $\begin{array}{l}2 \\
3\end{array}$ & $\begin{array}{l}\text { 'Sod layer' - gyttja, with plant remains and roots, dark brown } \\
\text { Gyttja, brown, 'leach layer' }\end{array}$ \\
\hline $1.90-6.13$ & 4 & Gyttja, greenish-brown \\
\hline $6.13-6.25$ & 5 & Silty gyttja \\
\hline $6.25-6.60+$ & 6 & Sand \\
\hline
\end{tabular}




\section{Field Work and Sample Preparation}

Sediment cores used for the magnetic analyses were collected on September 13, 1991, from a raft. The coring point is situated in the southeastern sector of the lake close to core 13 (Fig. 3). The water depth is $90 \mathrm{~cm}$. The uppermost $31 \mathrm{~cm}$ of the sediment succession was collected with a piston corer, while the remaining $540 \mathrm{~cm}$ was recovered by a Russian peat sampler. One- or two-centimetre slices of sediments from the piston corer as well as from the lowermost $40 \mathrm{~cm}$ were put into plastic bags. Five contiguous cores from $120 \mathrm{~cm}$ to $620 \mathrm{~cm}$, below the lake level, were transferred to D-shaped polystyrene tubes. All sediments were transported to Sweden. At the Department of Quaternary Research in Stockholm the material was transferred into polystyrene containers of $7 \mathrm{~cm}^{3}$ for the magnetic analyses. Samples from the cores were taken contiguously, each sample representing $2 \mathrm{~cm}$ of the sediment succession. The net weight of the wet sediment in each container was determined.

\section{Instrumentation and Magnetic Parameters}

The magnetic analyses were carried out on wet samples. After the completion of the analyses all samples were dried at $40{ }^{\circ} \mathrm{C}$ and reweighed. Mass specific parameters were calculated using the weight of the dried samples.

Initially the magnetic susceptibility of all samples was measured on an air-cored susceptibility bridge (Kappabridge). Magnetic susceptibility $(\chi)$ is a measure of the ease with which a material can be magnetised (see e. g. Thompson et al., 1975; Oldfield et al., 1978), and it is roughly proportional to the concentration of ferrimagnetic minerals within a sample. When ferrimagnetic minerals are very sparsely present, as in the case of the Lake Maardu samples, paramagnetic and antiferromagnetic and even diamagnetic minerals may contribute significantly to susceptibility.

Pulse magnetisers were used to artificially magnetise the samples. Magnetic saturation was achieved by placing each sample in a high magnetic field of $1 \mathrm{~T}$ (Tesla) produced by a Redcliff pulse magnetiser. The induced artificial remanence, resulting from this procedure, was measured on a Molspin spinner magnetometer. This parameter, produced in a high 'saturating' field, is called SIRM (Saturation Isothermal Remanent Magnetisation). It is probably the most useful artificially imparted remanence (Cisowski, 1980). Whereas susceptibility measurements take place in a low magnetic field generated by a coil, SIRM is a remanence measured after removal from the field. SIRM is mainly a measure of magnetite content, but it also depends on magnetic grain size and can be strongly influenced by other magnetic minerals like hematite. In contrast to susceptibility, SIRM is not affected by diamagnetic and paramagnetic minerals.

To differentiate between samples, it is often useful to place previously saturated and measured samples in a low reversed field. All samples from Lake Maardu were after the initial SIRM procedure placed in a weak negative field of $0.1 \mathrm{~T}$ (IRM-0.1T) using a Molspin pulse magnetiser and the remanence was similarly measured on the spinner magnetometer. By calculating the ratio of IRM-0.1T/SIRM (often called the 'S-ratio'; Thompson and Oldfield, 1986), it is possible to recognize samples with unusual hematite to magnetite ratios (Stober and Thompson, 1979). HIRM (High Induced Remanent Magnetisation) is the S-ratio expressed on an absolute basis and it is roughly a measure of the concentration of antiferromagnetic minerals in the sample. It is calculated as (1-|S|)SIRM/2. 


\section{Results}

In addition to the magnetic parameters, the percentage of dry material could be calculated based on the wet and dry weights at $40^{\circ} \mathrm{C}$ (Fig. 4). Apart from the lowermost sand, the dried material consists more or less entirely of organic material. The extremely low content of minerogenic particles in the organic sediments was clearly reflected in the very low raw values of susceptibility. Before correction for the diamagnetism of the sample holder, the container, and water content all numbers were negative.

The amount of dry material in the sand is around $75 \%$ and displays a rapid decrease in the overlying silty gyttja to about $15 \%$. In the lowermost part of the gyttja there is a more or less gradual and slower decrease to about $5 \mathrm{~m}$ from 15 to $8 \%$. Between 5 and $2 \mathrm{~m}$ the percentage of dry material ranges between 6 and $8 \%$ with a few outliers. From about this upper level there is a renewed increase. Samples in the topmost part have dry weights around $15 \%$, similar to the values found in the bottom of the gyttja. It can also be noted that the dry lake period is reflected as a drop in the percentage of dry material.
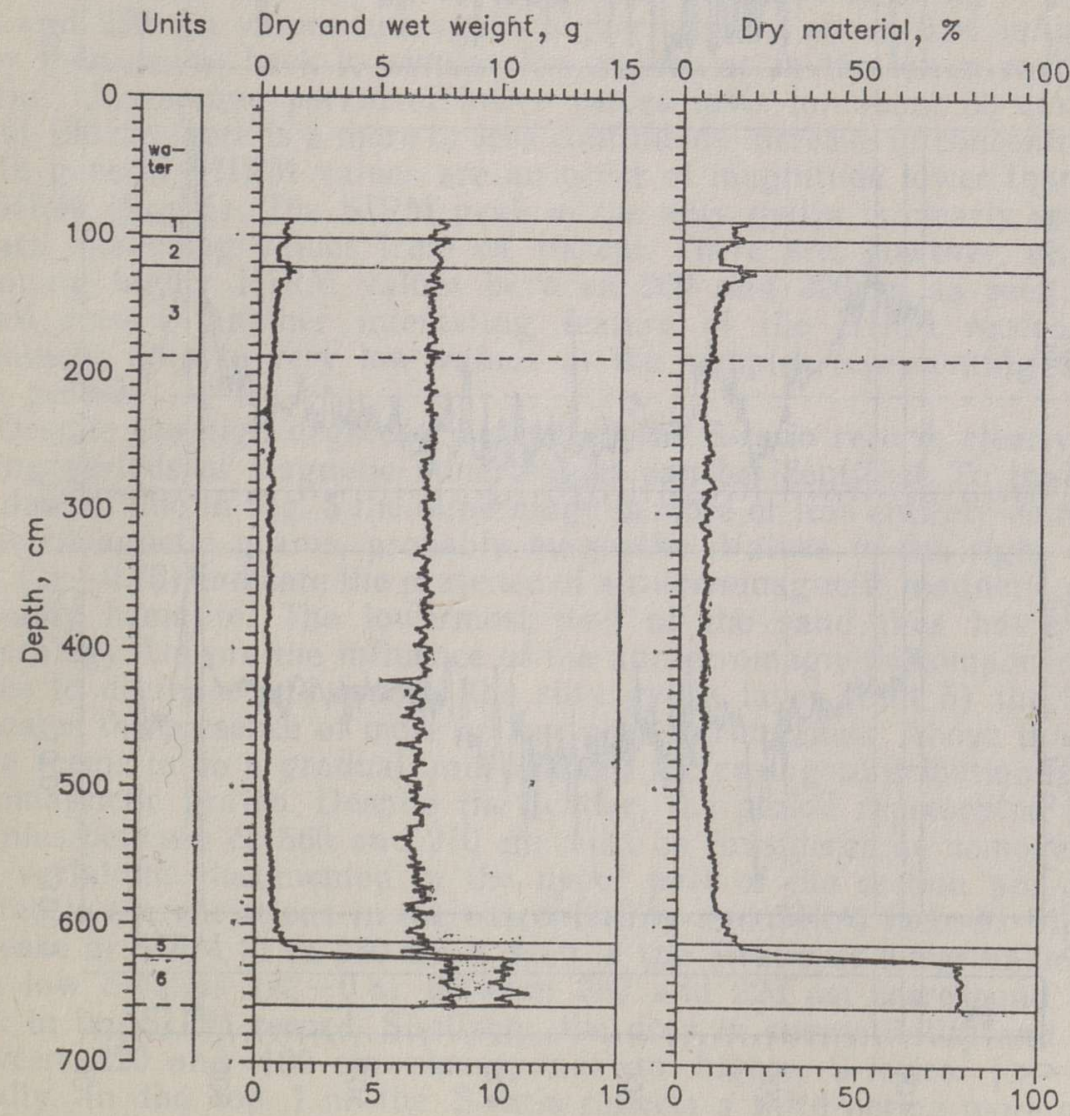

Fig. 4. Stratigraphical units of the sediments in Lake Maardu (see Table); wet and dry weight (after drying at $40^{\circ} \mathrm{C}$ ) and dry weight in percent of the wet weight. Note the drop in dry weight in unit 2 during the period when the lake was dried out. 

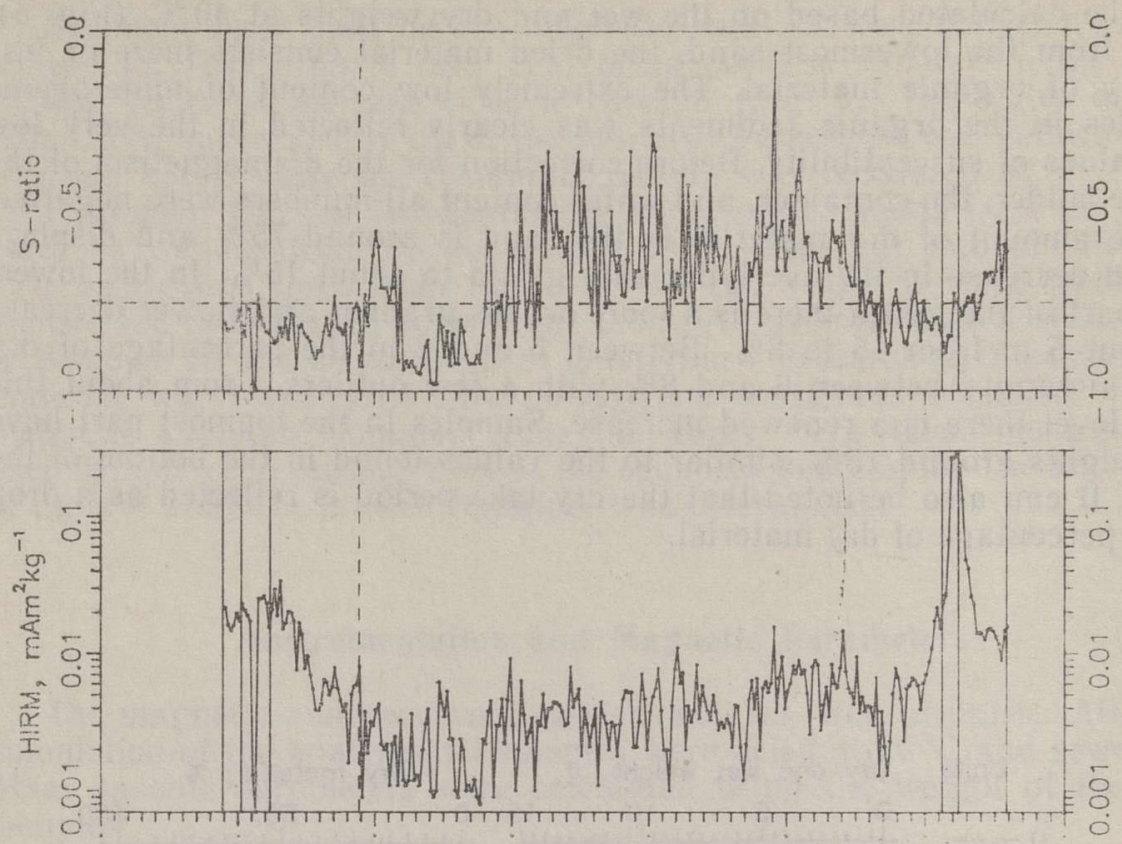

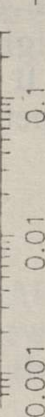
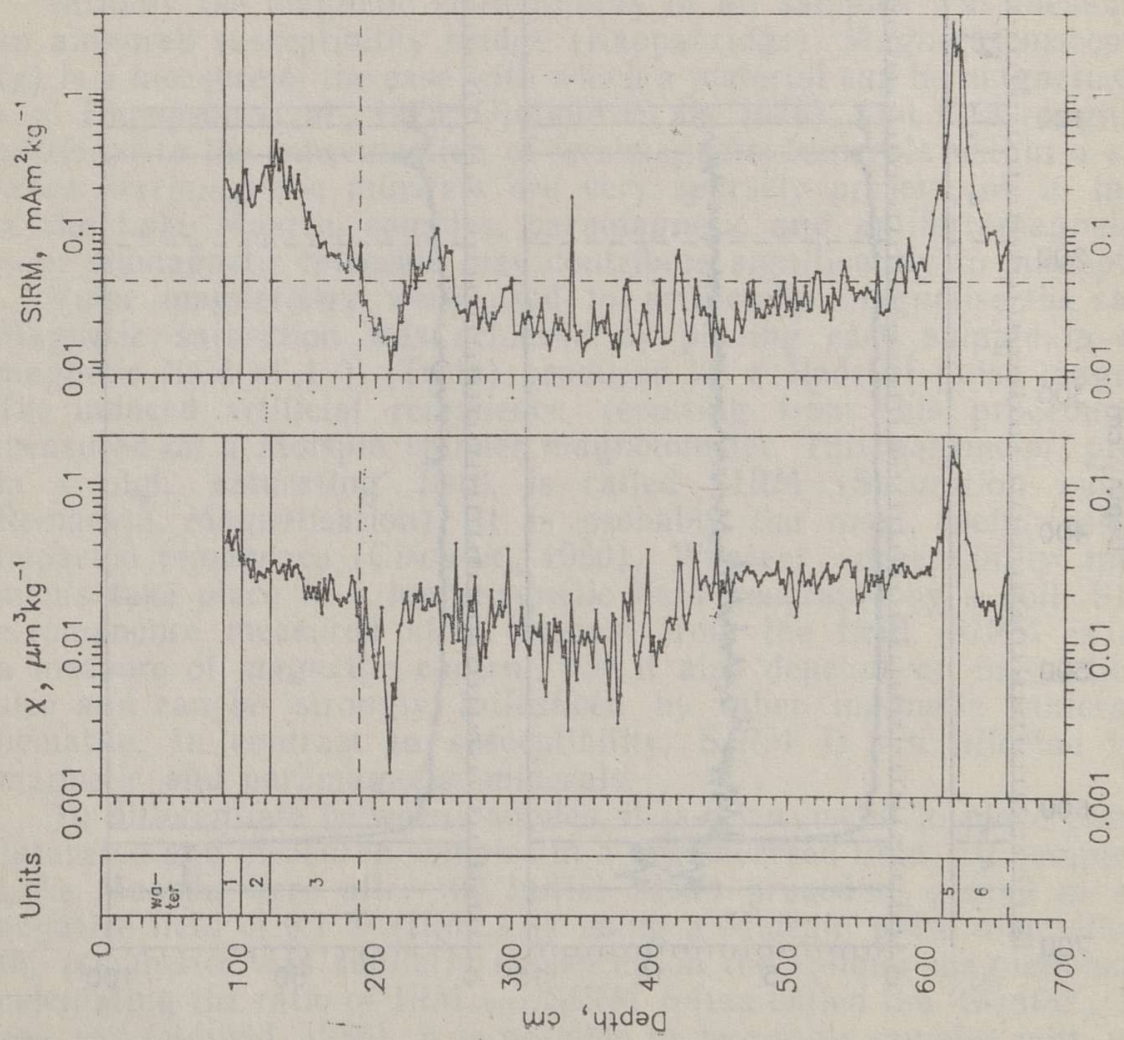
The magnetic values are somewhat scattered due to the low sample weights, typically $0.5 \mathrm{~g}$ (Fig. 4), and consequently very small amounts of magnetic grains in the organic parts, which are just enough to exceed the noise level of the susceptibility bridge and the spinner magnetometer. This fact is even more pronounced in the S-ratio and HIRM records.

Susceptibility (Fig. 5) generally ranges between 0.1 and $0.05 \mu \mathrm{m}^{3} \mathrm{~kg}^{-1}$ with a narrow peak in the middle of the silty gyttja exceeding $0.1 \mu \mathrm{m}^{3} \mathrm{~kg}^{-1}$. This peak value is about an order of magnitude higher than in the underlying sand. Despite the fact that the remaining part of the sediment section is a homogeneous gyttja, a number of features can be recognized in the susceptibility record. Between 600 and $420 \mathrm{~cm}$ values are stable, decreasing and stabilizing thereafter at a lower level. From about $280 \mathrm{~cm}$ there is a renewed tendency of increasing values. This trend, extending to the top, is interrupted by a segment of lower values between 220 and $190 \mathrm{~cm}$.

The trend of the SIRM record (Fig. 5) is in most respects a mirror of the susceptibility record. Differences between periods of lower and higher concentrations are however more pronounced. This is denoted by the arbitrary dashed line in Fig. 5. Values in the lower part of the sand are slightly lower than $0.1 \mathrm{mAm}{ }^{2} \mathrm{~kg}^{-1}$ but they increase gradually towards the upper boundary, displaying a pronounced peak in the overlying silty gyttja. This peak is followed by a relatively long sequence, to about $260 \mathrm{~cm}$, of lower values that range between 0.01 and $0.04 \mathrm{mAm}^{2} \mathrm{~kg}^{-1}$. Between 260 and $220 \mathrm{~cm}$ values are again higher, clearly above $0.04 \mathrm{mAm} \mathrm{kg}^{-1}$. They then swing back to similar low values as in the lower part of the gyttja. This second period of lower values lasts for about $30 \mathrm{~cm}$. From about $190 \mathrm{~cm}$ there is a more or less continuous increase in concentrations.

In general, HIRM values are an order of magnitude lower than those of SIRM (Fig. 5). The SIRM peak in the silty gyttja is clearly seen and so are increasing values from ca $190 \mathrm{~cm}$. There are, however, no corresponding higher HIRM values between 260 and $220 \mathrm{~cm}$ as seen in the SIRM record. Another interesting feature of the HIRM record is the prominent drop to very low values in the samples representing the dry lake period.

Despite the high degree of scatter in the S-ratio record, clearly alternating periods of magnetic mineralogies can be identified. To the left of the dashed line in Fig. 5 the mineralogy is more or less entirely dominated by ferrimagnetic grains, probably magnetite. Values to the right of this line $(>-0.75)$ indicate the presence of antiferromagnetic magnetic grains, probably hematite. The lowermost part of the sand thus has a mixed mineralogy. Upcore the influence of the antiferromagnetic component then seems to decrease and around the silty gyttja layer (unit 5) the S-ratio indicates the presence of more or less only ferrimagnets. Above this layer there seems to be a gradual and renewed increasing contribution of antiferromagnetic grains. Despite the scatter, the period represented by the samples between ca 560 and $270 \mathrm{~cm}$ must be considered as homogeneous. The variations documented in the upper part of the section are clearly related to the variations in the susceptibility and SIRM records. Thus the increase in SIRM at ca $280 \mathrm{~cm}$ is seen in the S-ratio as lower values. The very low S-ratios $(<-0.8)$ between 280 and $220 \mathrm{~cm}$ correspond to the peak in the SIRM record. Similarly, the drop in susceptibility and SIRM between 220 and $190 \mathrm{~cm}$ corresponds to higher S-ratios $(>-0.75)$. Finally, in the top $1 \mathrm{~m}$ the S-ratio reflects a third period more or less entirely devoid of antiferromagnetic grains corresponding to increasing and high values of SIRM and susceptibility. 


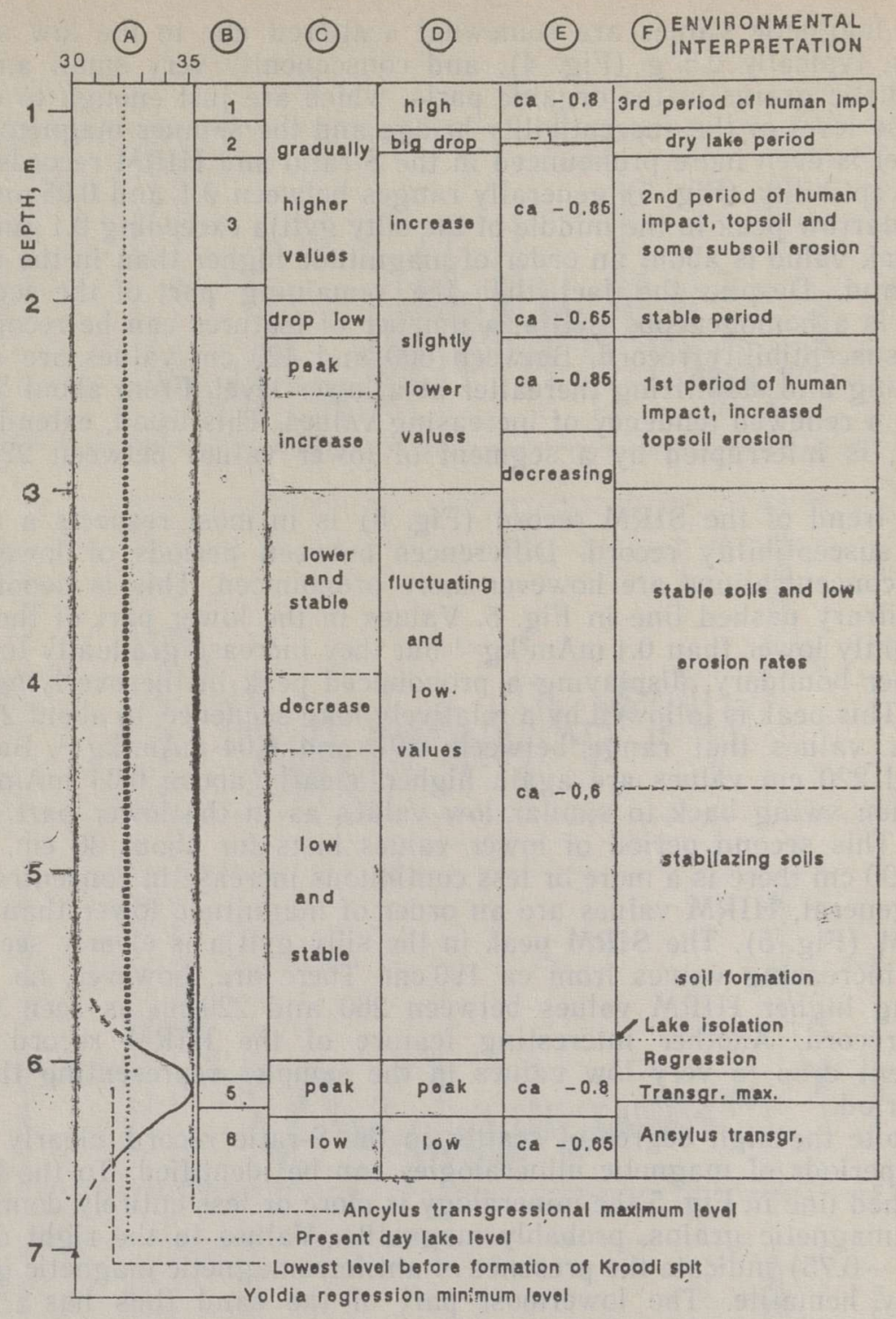

Fig. 6. Interpretation of water-level changes and environmental conditions in the Lake Maardu catchment related to relative variations in the magnetic parameters. Column A displays metres above the present-day water level. Levels of different Baltic stages in the bottom of the figure are based on (Caapce et al., 1990). Column B relates to the stratigraphical units described in the Table. The relative changes is susceptibility and SIRM, HIRM, and the S-ratio are shown in columns C, D, and E, respectively. The environmental interpretation based on the magnetic parameters is summarised in column $\mathrm{F}$. 


\section{Interpretation}

The conclusions that can be based on these results are, at the present stage, limited by the fact that the variations in the magnetic records are not supported by other types of independent data or at least by the fact that data available are not readily transferable to the investigated sediment succession. A simplifying factor, on the other hand, is possibly the homogeneous nature of the sediments. Bearing these circumstances and limitations in mind, the magnetic records of the Lake Maardu sediments have been interpreted in the following way (summarised in Fig. 6).

The peak in magnetic concentrations in the silty gyttja layer (Fig. 4) with even lower susceptibility values in the sand than in the overlying gyttja is interpreted as the result of variations in particle size. Björck et al. (1980) found a strong tendency for the highest susceptibility to be associated with the coarse silt and fine sand fractions, approximately in the $32-250 \mu \mathrm{m}$ particle size range. This is in good agreement with the composition of the sediments in the bottom of Lake Maardu. The coarsest particles and correspondingly relatively low susceptibility characterize the sand. Along with a shift to finer particles in the silty gyttja there is an increase in susceptibility. The gradual change to even finer particles in the overlying gyttja leads to a decrease in susceptibility.

The variations in the S-ratio in the bottom of the sediment succession indicate a gradual change in magnetic mineralogy not related to the variations in particle size reflected in the susceptibility record. The S-ratio in the lowermost part of the sand and the gyttja above, to about $300 \mathrm{~cm}$, point to a mixed mineralogy consisting of both ferrimagnetic and antiferromagnetic grains. In the intervening part, around the silty gyttja layer, S-ratios point to the absence of or very low admixture of antiferromagnetic grains. This change in mineralogical composition could, however, be explained as a result of the lake receiving material from different sources. During the Yoldia Sea regression, the water level dropped and stabilized at $30 \mathrm{~m}$ (Fig. 2). This level is below the estimated threshold of $31.5 \mathrm{~m}$ (Caapce et al., 1990), indicating that the lake has been isolated. Vast amounts of sand of local origin were deposited during this regressional phase. This sand nowadays partly makes up the surficial deposits as well as the substratum in the present-day lake. During the following Ancylus transgression, the water level rose to $35 \mathrm{~m}$. Material of slightly different composition was washed into the basin, reflected in the lower S-ratios in the top part of the sand and the overlying silty gyttja. After the isolation the basin has only received material of "local" origin. This "local" material has an S-ratio of ca -0.6, similar to that found in the bottom of the sand.

After the final isolation and immigration of plants and stabilisation of the soils, very little minerogenic matter has been deposited in the lake. Some may be of aeolian origin as no major streams enter the lake. During this period, represented by the sediments to about $300 \mathrm{~cm}$, susceptibility and SIRM first show a slight decrease, to about $500 \mathrm{~cm}$, then stabilize at a lower level. The higher susceptibility values between 600 and ca $450 \mathrm{~cm}$ compared to the SIRM is probably due to a higher proportion of paramagnetic minerals. This is supported by the amount of quartz documented in core 6 (Caapce et al., 1990, Fig. 5).

From about $280 \mathrm{~cm}$ both susceptibility and SIRM increase again and in the SIRM record there is a well-defined peak around $240 \mathrm{~cm}$. This increase in magnetic concentrations is accompanied by lower S-ratios. The admixture of antiferromagnetic grains disappears and S-ratios are typically $<-0.8$. These changes are assumed to reflect a change in the environment and considered as the result of a 'first period of human impact' in 
the catchment. The increased erosion is reflected in the higher concentrations of magnetic minerals. This erosion is assumed to be of topsoil origin. The S-ratios are lower due to fine secondary magnetite grains eroded from the topsoils. The two main processes that are thought to be responsible for the formation of secondary magnetic minerals from weakly paramagnetic iron minerals in topsoils are (i) pedogenic-oxidation cycles and (ii) burning (Mullins, 1977; Tite and Linington, 1975; Maher, 1986). A third possibility, unlikely at this depth, is that this so-called magnetic "enhancement" is caused by "industrial revolution" pollution from atmospheric deposition of magnetic minerals produced by coal burning in chimneys. Efforts to prove the presence of these fine grains with ARM analyses or determination of the frequency-dependent magnetic susceptibility failed due to very low concentration of magnetic minerals in the samples. This first period of human influence was followed by a period of renewed stabilization. Then magnetic concentrations decrease again and the S-ratio increases to similar values as before this event.

A second period of human impact is believed to start at the $190 \mathrm{~cm}$ level. From this level there is a more or less constant increase in magnetic concentrations accompanied by S-ratios generally $>-0.8$. This interpretation is supported by the pollen diagram (Caapce et al., 1990, Fig. 6) with the first occurrence of Ceralia pollen at $225 \mathrm{~cm}$. After the dry lake period, ending 1939, water has been pumped into the lake. This could possibly explain the even higher susceptibility values found in the very top of the sediments.

An interesting feature worth noting is that the uppermost sample from the dry lake period has a very low S-ratio $(-1)$ accompanied by a significant drop in HIRM. As the lake was dried out, no sediments were deposited and this feature could possibly be explained by atmospheric deposition of secondary magnetic minerals from coal burning, as described above.

\section{Acknowledgements}

The cores used for the magnetic analyses were collected by Atko Heinsalu and Siim Veski at the Institute of Geology, Estonian Academy of Sciences. Dr. Jan Risberg at the Department of Quaternary Research in Stockholm, Sweden, carried out the subsampling. The manuscript has been critically reviewed by Dr. Leili Saarse. Financial support is acknowledged from the Swedish Natural Research Council (NFR).

\section{REFERENCES}

Brirck, S., Dearing, J. A., and Jonsson, A. 1980. Magnetic susceptibility of Late Weichselian deposits in S. E. Sweden. - Boreas, 11, 99-111.

Cisowski, S. W. 1980. The relationship between the magnetic properties of terrestrial igneous rocks and the composition and internal structure of their component Fe-oxide grains. - Geophys. J. Royal Astron. Soc., 60, 107-122.

Maher, B. A. 1986. Characterization of soil by mineral magnetic measurements. Physics of Earth and Planetary Interiors, 42, 76-92.

Mullins, C. E. 1977. Magnetic susceptibility of the soil and its significance in soil science: A review. - J. Soil Sci., 28, 223-246.

Oldlield, F., Dearing, J. A., Thompson, R., and Garret-Jones, S. E. 1978. Some magnetic properties of lake sediments and their possible links with erosion rates. Polskie Archive. Hydrobiologica, 25, 321-331. 
Stober, J. C. and Thompson, R. 1979. Magnetic remanence acquisition in Finnish lake sediments. - Geophys. J. Royal Astron. Soc., 57, 727-739.

Thompson, R., Batterbee, R. W., O'Sullivan, P. E., and Oldfield, F. 1975. Magnetic susceptibility of lake sediments. - Limnol. Oceanogr., 20, 687-698.

Thompson, R. and Oldfield, F. 1986. Environmental Magnetism. Allen \& Unwin, London.

Tite, M. S. and Linington, R. E. 1975. Effect of climate on the magnetic susceptibility of soils. - Nature, 265, 565-566.

Саарсе Л., Вески С., Раямяэ Р., Сарв А., Хейнсалу А. 1990. Геология озера Маарду. АН Эстонии, Таллинн (Preprint).

Presented by A. Miidel

Received

September 15, 1992

Per SANDGREN

\section{MAARDU LABILOOIKE MINERAALIDE MAGNETISMI ANALUUSI ESIALGSED TULEMUSED}

Mõõdeti Maardu järve põhjasetete mineraalide magnetilisi parameetreid. Nende muutused korreleeruvad hästi keskkonna looduslike ja antropogeensete muutustega, eriti sügavuses 280 ja $180 \mathrm{~cm}$. Nimetatud sügavuses suureneb valgalalt järve sissekantud mineraalse materjali hulk. Seda on seostatud inimtegevuse laienemisega järve valgalal.

Пер САНДГРЕН

\section{РЕЗУЛЬТАТЫ МИНЕРАЛЬНО-МАГНИТНОГО АНАЛИЗА ГОЛОЦЕНОВЫХ ОТЛОЖЕНИИ ОЗ. МААРДУ}

Установлено, что изменения минерально-магнитных параметров в донных осадках оз. Маарду хорошо коррелируются с изменениями природных и антропогенных ландшафтов. Антропогенные изменения наиболее существенны на глубинах 2,80 и 1,80 м, так как на этих уровнях отмечается повышенный привнос терригенного компонента. 